\title{
A New Late-ripening Chinese Chestnut Cultivar, Jianding Youli
}

\author{
Cancan Zhu, Liu Liu, Min Wang, Yuqiang Zhao, and Yu Chen \\ Institute of Botany, Jiangsu Province and Chinese Academy of Sciences, \\ Nanjing 210014, China
}

Xiaomei Lu
Changzhou Guomei Agricultural Technology Corporation Limited,
Changzhou, 213000, China

Guomin Geng ${ }^{1}$

Institute of Botany, Jiangsu Province and Chinese Academy of Sciences, Nanjing 210014, China

Additional index words. fruit character, UPOV guideline, roasting, nut quality, yield

A new Chinese chestnut cultivar, Jianding Youli (Castanea mollissima Blume), was released from native chestnut trees in China by Institute of Botany, Jiangsu Province, and Chinese Academy of Sciences in 2017. This cultivar was preliminary selected from a natural seedling tree in Shandong Province in 1963. Then, the advanced and regional yield trials for evaluation were carried out from 1975 to 2016. Jianding Youli is a lateripening cultivar with an optimal ripening date in late September. It has good nut quality for eating raw and processing, and it is especially suitable for sugar-frying processing. The average nut weight is $10.8 \mathrm{~g}$. It is easily identified by the acute tip on the blossom of nuts and reddish-brown, glossy shell. It also has been found to be resistant to chestnut blight disease and the chestnut weevil. This gives it suitable features for storage. It has high yield potential, and the average yield of an 8-year old 'Jianding Youli' was $8.8 \mathrm{~kg}$ per tree.

\section{Origin}

The first general survey of Chinese chestnut resources was carried out from 1961 to 1963. Jianding Youli (Castanea mollissima Blume) cultivar was selected in 1963 from indigenous individual located at Tancheng County, Shandong Province, People's Republic of China (lat. $34^{\circ} 38^{\prime} 1.07^{\prime \prime} \mathrm{N}$, long. $118^{\circ} 11^{\prime} 1.18^{\prime \prime} \mathrm{E}$, elevation $67 \mathrm{~m}$ ). This area is situated in the warm temperate zone of China, belonging to the warm temperate zone monsoon climate. The type of the soil

Received for publication 26 Nov. 2018. Accepted for publication 17 Jan. 2019.

This work was supported by the National Natural Science Foundation of China (grant no. 31500514) and the Key Research and Development Program (Modern Agriculture) Project of Jiangsu Province Science and Technology Department (grant no. BE2016385).

${ }^{1}$ Corresponding author. E-mail: 13951970164@ 163.com. is brown soil. Trees of this cultivar are vigorous and produce abundant heavy fruits uniformly throughout the fruiting season. This cultivar is easy to identified by the acute tip on the blossom and reddish-brown, glossy nutshell. Finally, this cultivar also shows resistance to chestnut blight disease and the chestnut weevil.

\section{Description and Performance}

Using scion grafting, more than 60 Chinese chestnut cultivars including 'Jianding Youli' (Castanea mollissima Blume) were tested for propagation in the experimental nursery in Institute of Botany, Jiangsu Province, and Chinese Academy of Sciences in 1975. The first selection was conducted from 1975 to 1985 . From 1990 to 2016, the regional adaptation and advanced trails for examination of each individual tree's characteristics and productivity were initiated in the Chinese Chestnut experimental nursery of Institute of Botany, Jiangsu Province and Chinese Academy of Sciences, Nanjing, China (lat. $32^{\circ} 03^{\prime} 20.79^{\prime \prime} \mathrm{N}$, long. $118^{\circ} 49^{\prime} 53.377^{\prime \prime}$ E, elevation $48 \mathrm{~m}$ ). This area has a north subtropical humid monsoon climate and the landform here is mainly low mountains and gentle hills. The cultivar Jiujiazhong (C. mollissima) was used as a standard for comparison. Native to China, this cultivar has good yields, large fruit, and has been generally cultivated in Yangtze Plain of China.

We evaluated the new Jianding Youli cultivar and the reference cultivar Jiujiazhong for bursting time of leaf bud and leaf characteristics, flowering, fructification characteristics, harvesting time, yield, morphological nut characteristics, and nut traits on 10 grafted trees (2 years after grafting, seedlings as rootstocks) according to guidelines for the conduct of tests for distinctness, uniformity, and stability in chestnuts (Castanea mollissima Blume) (LY/T 1851-2009, UPOV TG/124/3, UPOV 2017). The contents of soluble sugar, starch, soluble protein, crude fat, and vitamin $\mathrm{C}$ of the nuts also were investigated using plant biochemical methods. The values provided are the averages of 3 years of data collection, 2011 to 2014.

For bursting time of leaf bud and leaf characteristics, 'Jianding Youli' bursts into leaf bud around $10 \mathrm{Apr}$., and it is observed to be $1 / 2$ or partially $2 / 5$ in phyllotaxis. Leaves are needle-shaped elliptic to oval. 'Jianding Youli' has a dentate incision shape of the leaf margin, a cordate shape of the leaf blade base, leaf length to leaf width ratio of 2.75 , and a leaf length to petiole length ratio of 14 (Table 1).

The cultivar shows a semierect tree shape (Fig. 1). The diameter of the tree trunk (after first growing season, below first branch) is large, and the bearing mother branches are short and thick, with the length of internodes of current season's lateral is $1.5 \mathrm{~cm}$. Also, the densities of lenticels on the laterals are dense. The dormant bud of the cultivar is reddish brown in color with hairs. This cultivar was observed to have tolerance to chestnut blight disease and the chestnut weevil (data not shown).

The pistillate flowering period is from 29 May to 15 June with a full bloom from 6 June to 11 June. The staminate flowering period of 'Jianding Youli' is from 2 June to 20 June with a full bloom from 8 June to 15 June (Table 2). The male catkin is of medium length, and the type of catkins is longistaminate, based on the International Union for the Protection of New Varieties of Plants guidelines.

Jianding Youli is an early-ripening, highyield cultivar. It has high sprouting power. Fruiting ability of the bearing mother branches on this cultivar is well developed. The bearing branches of juvenile tree easily produce branchlets and are tolerant to pruning (Table 3 ). The average plant yield of 2year-old grafted seedlings was $0.55 \mathrm{~kg}$ of nuts, and the highest yield of 3-year-old grafted trees was $12.3 \mathrm{~kg}$.

'Jianding Youli' has short, dense burs. The fruit is transverse broad ellipsoid in shape with an acute tip (Fig. 2). The shell is reddish-brown, glossy, and easy to peel. This variety produced larger nuts than other varieties, with the nut height to nut width ratio of $1.08 \pm 0.03$, a hilum length to nut width ratio of $1.15 \pm 0.06,0.0 \%$ polyembryonic nuts, $0.13 \%$ pericarp splitting, and weak degree of penetration of the seedcoat into the kernel (Table 4). We predict that this cultivar has great potential future product value for processing use because it is monoembryonic, has lower pericarp splitting, and has a low percentage of penetration of the seedcoat into the kernel.

The average single nut weight is $10.8 \mathrm{~g}$ and the nut kernel rate is $49.2 \%$. The kernel is fine, glutinous, and sweet, with soluble sugar content of $20.56 \%$, starch content of $39 \%$, starch gelatinization temperature of $57.2{ }^{\circ} \mathrm{C}$, and the soluble solid content of $16.2 \%$ after harvesting (Table 5). This chestnut cultivar is suitable for roasting and stir-frying.

The cultivar Jianding Youli did not show obvious symptoms of weevil and Dichocrocis punctiferalis Guenée infestation. In 2016, 
Table 1. Time of leaf bud burst and leaf characteristics of 'Jianding Youli' and 'Jiujiazhong'.

\begin{tabular}{|c|c|c|c|c|c|c|c|}
\hline Cultivars & $\begin{array}{l}\text { Bursting time } \\
\text { of leaf bud }\end{array}$ & Phyllotaxis & $\begin{array}{c}\text { Cross section } \\
\text { of leave }\end{array}$ & $\begin{array}{l}\text { Incisions of } \\
\text { leaf margin }\end{array}$ & $\begin{array}{l}\text { Shape of base } \\
\text { of leaf blade }\end{array}$ & $\begin{array}{l}\text { Leaf length/ } \\
\text { leaf width }\end{array}$ & $\begin{array}{l}\text { Leaf length/ } \\
\text { petiole length }\end{array}$ \\
\hline Jianding Youli & 10 Apr. & $1 / 2,2 / 5$ & Straight & Dentate & Cordate & $2.8 \pm 0.23 \mathrm{~b}$ & $14 \pm 1.61 \mathrm{~b}$ \\
\hline Jiujiazhong & 13 Apr. & $1 / 2,2 / 5$ & Slightly concave & Dentate & Obtuse & $2.2 \pm 0.87 \mathrm{a}$ & $11 \pm 2.55 \mathrm{a}$ \\
\hline
\end{tabular}

Means \pm SD done by $t$ test (Duncan's multiple range test) at $P=0.05$ on 10 plants per cultivar $(\mathrm{n}=20)$; similar letters within a column indicate no significant differences.

$\mathrm{UPOV}=$ International Union for the Protection of New Varieties of Plants.

Table 2. Flowering period of 'Jianding Youli' and 'Jiujiazhong'.

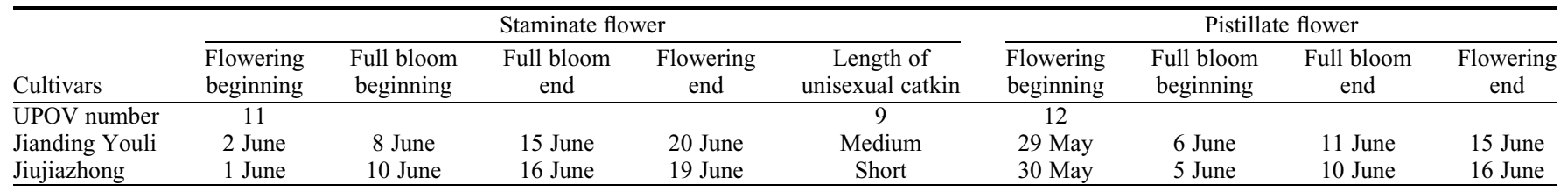

UPOV = International Union for the Protection of New Varieties of Plants.

Table 3. Flowering and fructification characteristics of 'Jianding Youli' and 'Jiujiazhong'.

\begin{tabular}{|c|c|c|c|c|c|}
\hline Cultivar & $\begin{array}{l}\text { No. of pistillate flowers } \\
\text { per bearing branchy }\end{array}$ & $\begin{array}{l}\text { No. of bearing branch per } \\
\text { bearing mother branch }\end{array}$ & $\begin{array}{l}\text { No. of burs per } \\
\text { bearing branch }\end{array}$ & $\begin{array}{l}\text { Seed-setting } \\
\text { rate }(\%)\end{array}$ & $\begin{array}{l}\text { Empty shell } \\
\text { rate }(\%)\end{array}$ \\
\hline Jiujiazhong & $1.77 \pm 0.38 \mathrm{~b}$ & $2.51 \pm 0.32 \mathrm{~b}$ & $2.77 \pm 0.20 \mathrm{a}$ & $82.58 \pm 5.53 \mathrm{a}$ & $2.43 \pm 0.41 \mathrm{~b}$ \\
\hline
\end{tabular}

Means \pm SD done by $t$ test (Duncan's multiple range test) at $P=0.05$ on 10 plants per cultivar $(\mathrm{n}=20)$; similar letters within a column indicate no significant difference.

Table 4. Harvesting time, yield, and morphological nut characteristics of 'Jianding Youli' and 'Jiujiazhong'.

\begin{tabular}{|c|c|c|c|c|c|c|c|c|c|}
\hline Cultivars & $\begin{array}{c}\text { Optimal } \\
\text { harvest } \\
\text { time }\end{array}$ & $\begin{array}{c}\text { Yield } \\
\text { (kg/tree) }\end{array}$ & Nut shape & $\begin{array}{l}\text { Nut ht/nut } \\
\text { width }\end{array}$ & $\begin{array}{l}\text { Hilum length/ } \\
\text { nut width }\end{array}$ & $\begin{array}{c}\text { Percent of } \\
\text { Polyembryonic } \\
\text { nuts }^{\mathrm{z}}(\%)\end{array}$ & $\begin{array}{l}\text { Percent with } \\
\text { the pericarp } \\
\text { split }^{2}(\%)\end{array}$ & $\begin{array}{l}\text { Penetration } \\
\text { of the } \\
\text { seedcoat } \\
\text { into kernel }\end{array}$ & $\begin{array}{c}\text { Degree of } \\
\text { penetration of } \\
\text { the seedcoat } \\
\text { into kernel }\end{array}$ \\
\hline $\begin{array}{l}\text { UPOV } \\
\text { number }\end{array}$ & & & 31 & & & 27 & & 29 & 30 \\
\hline $\begin{array}{l}\text { Jianding } \\
\text { Youli }\end{array}$ & September 28 & $7.46 \pm 1.05 \mathrm{a}^{\mathrm{y}}$ & $\begin{array}{l}\text { Transverse broad } \\
\text { ellipsoid with } \\
\text { acute tip }\end{array}$ & $1.08 \pm 0.03 \mathrm{~b}^{\mathrm{y}}$ & $1.15 \pm 0.06 \mathrm{~b}^{\mathrm{y}}$ & $0.0 \mathrm{a}^{\mathrm{y}}$ & $0.13 \pm 0.007 \mathrm{a}^{\mathrm{y}}$ & Present & Weak \\
\hline
\end{tabular}

${ }^{\mathrm{z}}$ Measured during the third and the fourth week of September.

${ }^{\mathrm{y}}$ Measured 8 years old for yield; Means \pm SD done by $t$ test (Duncan's multiple range test) at $P=0.05$ on 10 plants per cultivar (n $=20$ ); similar letters within a column indicate no significant difference.

$\mathrm{UPOV}=$ International Union for the Protection of New Varieties of Plants.

the observation results showed that the percentage of nuts damaged by insects was $8.2 \%$, much lower than that of the Jiujiazhong cultivar (Table 6).

\section{Notes and Spreading Prospects in Cultivation}

'Jiandang Youli' is a high-quality chestnut suitable for roasting, especially in the south of China. This cultivar has early-bearing, highyielding characteristics, and good storage tolerance. It can be planted in the north and south areas of Jiangsu Province in China. It grows rapidly and has strong adaptability. It is also an excellent ecological greening tree species. Because 'Jianding Youli' is a cultivar bearing heavy fruiting in young trees, this cultivar could show large nuts and annual fructification. This cultivar does demand proper pruning and fertilizer control to maintain tree vigor continuously (Kim et al., 2008).

On the basis of the origin and experimental ecological conditions, this cultivar prefers a warm and humid climate and is more suitable for extensive cultivation that uses few inputs of labor and fertilizers.
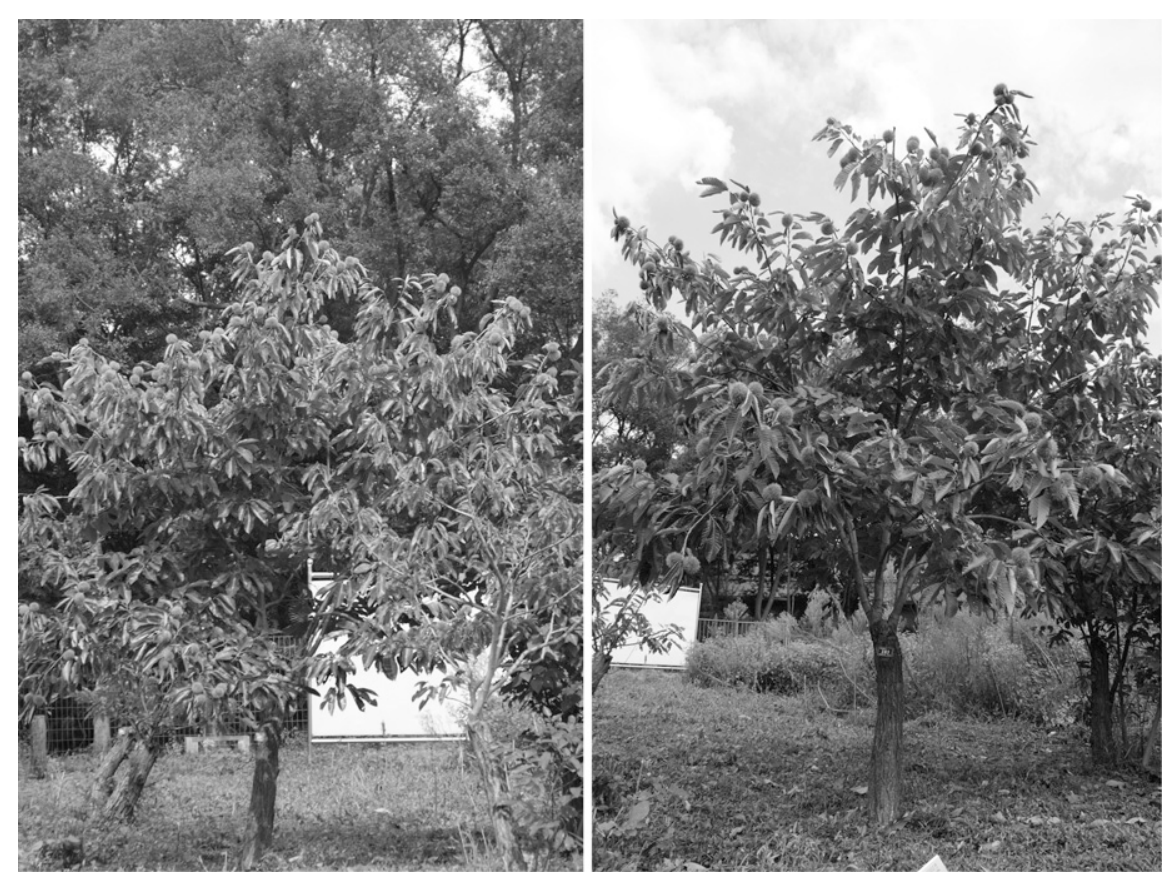

Fig. 1. 'Jiujiazhong' (left) and 'Jianding Youli' (right) trees in late September. 


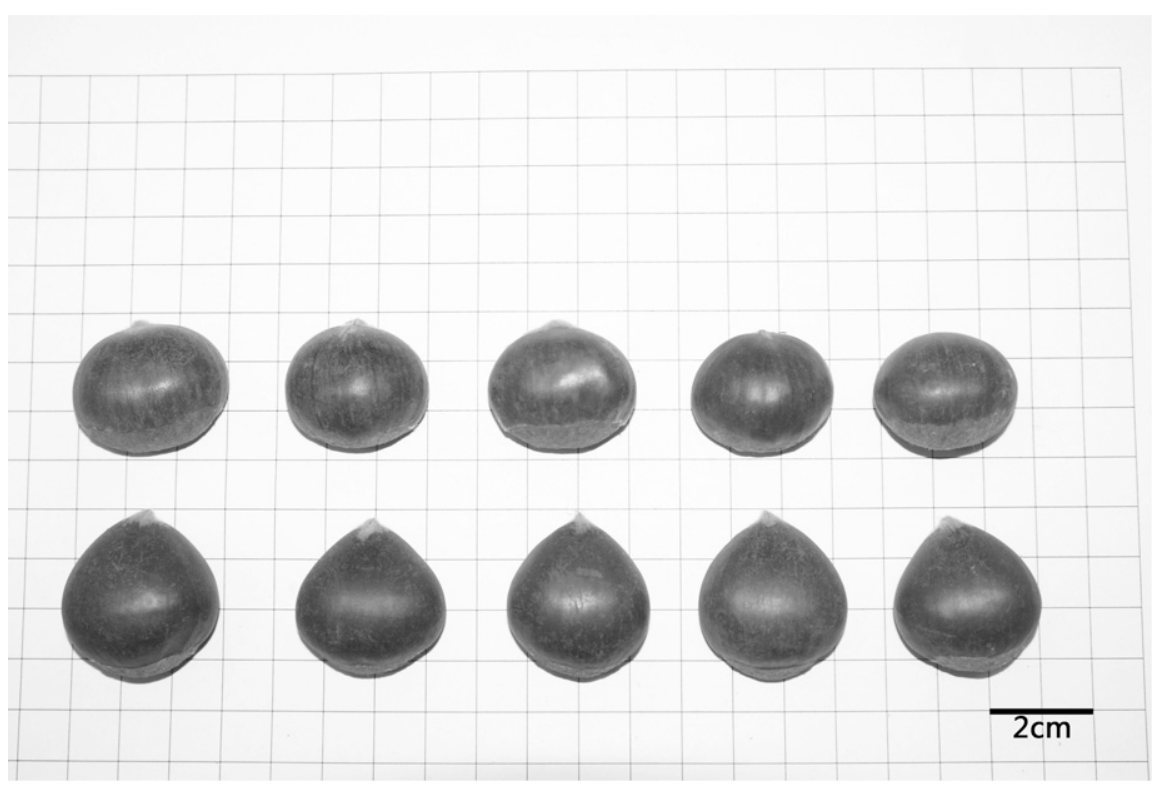

Fig. 2. Nut size and nut shape (upper row: 'Jiujiazhong', lower row: 'Jianding Youli').

Table 5. Nut traits of 'Jianding Youli' and 'Jiujiazhong'.

\begin{tabular}{|c|c|c|c|c|c|c|c|}
\hline Cultivars & $\begin{array}{l}\text { Nut wt } \\
\text { (g) }\end{array}$ & $\begin{array}{c}\text { Moisture } \\
\text { content (\%) }\end{array}$ & $\begin{array}{c}\text { Soluble } \\
\text { sugar } \\
\text { content (\%) }\end{array}$ & $\begin{array}{c}\text { Starch } \\
\text { content (\%) }\end{array}$ & $\begin{array}{c}\text { Starch } \\
\text { gelatinization } \\
\text { temp }\left({ }^{\circ} \mathrm{C}\right)\end{array}$ & $\begin{array}{c}\text { Crude } \\
\text { protein } \\
\text { content }(\%)\end{array}$ & $\begin{array}{c}\text { Crude fat } \\
\text { content (\%) }\end{array}$ \\
\hline $\begin{array}{r}\text { Jianding } \\
\text { Youli }\end{array}$ & $10.8 \pm 0.85 \mathrm{a}$ & $48.6 \pm 1.23 \mathrm{~b}$ & $20.56 \pm 1.08 \mathrm{~b}$ & $39 \pm 1.47 \mathrm{a}$ & $57.2 \pm 1.03 \mathrm{a}$ & $6.92 \pm 1.25 \mathrm{a}$ & $1.8 \pm 0.96 \mathrm{a}$ \\
\hline Jiujiazhong & $13.1 \pm 0.92 \mathrm{~b}$ & $45.8 \pm 1.79 \mathrm{a}$ & $15.76 \pm 1.43 \mathrm{a}$ & $45.7 \pm 1.09 \mathrm{~b}$ & $59.0 \pm 0.87 \mathrm{ab}$ & $7.22 \pm 1.08 \mathrm{~b}$ & $2.0 \pm 1.27 \mathrm{~b}$ \\
\hline \multicolumn{8}{|c|}{$\begin{array}{l}\text { Means } \pm \text { SD done by } t \text { test (Duncan's multiple range test) at } P=0.05 \text { on } 10 \text { plants per cultivar }(\mathrm{n}=20) \text {; } \\
\text { similar letters within a column indicate no significant difference. }\end{array}$} \\
\hline \multicolumn{8}{|c|}{ 6. Nut infestation rate of 'Jianding Youli' and 'Jiujiazhong'. } \\
\hline Cultivars & & \multicolumn{2}{|c|}{$\begin{array}{l}\text { Total number } \\
\text { of nuts }\end{array}$} & \multicolumn{2}{|c|}{$\begin{array}{l}\text { Number of insect- } \\
\text { damaged fruit }\end{array}$} & \multicolumn{2}{|c|}{$\begin{array}{l}\text { Percentage of insect- } \\
\text { damaged fruit }(\%)\end{array}$} \\
\hline \multicolumn{2}{|c|}{ Jianding Youli } & \multicolumn{2}{|c|}{146} & \multicolumn{2}{|c|}{12} & \multicolumn{2}{|c|}{8.2} \\
\hline \multicolumn{2}{|c|}{ Jiujiazhong } & \multicolumn{2}{|l|}{163} & \multicolumn{2}{|l|}{58} & \multicolumn{2}{|c|}{35.5} \\
\hline
\end{tabular}

\section{Availability}

On 10 March, 2017, the Chinese chestnut cultivar Jianding Youli was granted cultivar protection by the Forest Variety Approval Committee of Jiangsu Forestry Bureau with a certificate no. SU-S-SV-CM-014-2017. Nurseries interested in a propagating program may contact the Institute of Botany, Jiangsu Province and Chinese Academy of Sciences, Nanjing, China or 13951970164@163.com.

\section{Literature Cited}

LY/T 1851-2009. Guidelines for the conduct of tests for distinctness, uniformity and stability-Chestnut (Castanea mollissima B1.). Forestry Industry Standards of the People's Republic of China.

UPOV (International Union for the Protection of New Varieties of Plants). 1989. Guidelines for the conduct of tests for distinctness, homogeneity and stability. Chestnut (Castanea sativa Mill.). TG/124/3 (ed). International Union for the Protection of New Varieties of Plants, Geneva.

UPOV (International Union for the Protection of New Varieties of Plants). 2017. Chestnut (Castanea mollissima Blume; Castanea crenata Siebold \& Zucc.; Castanea sativa Mill.); guidelines for the conduct of tests for distinctness homogeneity and stability. UPOV, Geneva, Switzerland.

Kim, M.J., U. Lee, K.O. Byun, M.H. Lee, M.S. Jung, and Y.H. Kwon. 2008. New late-ripening large-nut indigenous Korean Chestnut Cultivar, Mipung. HortScience 43:1918-1919. 